\title{
WhatsApp Group Application: Increasing or Decreasing The Closeness
}

\author{
Hanny Hafiar ${ }^{1}$, La Ode Herman ${ }^{2}$, La Tarifu ${ }^{3}$, Sitti Utami Rezkiawaty Kamil ${ }^{4}$, Faturachman \\ Alputra Sudirman $^{5}$, Fera Tri Susilawaty ${ }^{6}$, Ari Agung Prastowo ${ }^{7}$ \\ \{email:hanny.hafiar@unpad.ac.id; ari.agungi@unpad.ac.id\} \\ 1,7 Universitas Padjadjaran, Bandung, Indonesia \\ 2,3,4,5,6 Universitas Halu Oleo, Kendari, Indonesia
}

\begin{abstract}
The contestation of presidential elections tends to color the content of public talks. This includes students from the Faculty of Social and Political Sciences, at Halu Oleo University, which is channeled through WhatsApp Group (WAG). Differences in the choice between users often lead to conflict. Therefore, this article aims to describe the merger and number of WAGs that are followed, conflicts that occur in the WAG, acts of leave groups conducted by WAG members, as well as comments given after the leave group event by one of the members related to the conflict. The method used in this study is using the quantitative descriptive method, where data is collected through questionnaires to 201 respondents as samples, observations, and interviews to selected samples. The results showed that most students attended a number of WAGs. In some WAGs that followed, there were conflicts relating to presidential elections which led to the leave group action conducted by WAG members. The debate and conflict that occurred on the WhatsApp group, showed that as a communication media, WhatsApp Group had a role in increasing, while reducing the level of closeness among group members. Even though the initial goal of group formation was based on the desire to establish closer communication between members who were friends and partners. The awareness of members on the initial purpose of forming WAG is expected to minimize possible conflicts in the WAG, so that the conditions of relations between members can be harmonious
\end{abstract}

Keywords: application, WhatsApp Group, Students, Politics.

\section{Introduction}

The era of digital information has led to a shift in people's choices regarding information media. If in the previous era the dissemination of information was dominated through mass media channels such as television, newspapers, and printed magazines, as well as radio, now the dissemination of the information found new channels through digital communication media. One of the advantages of disseminating information through digital, besides being able to do it in real time, also opens opportunities for interactive communication between the sender and the recipient of the message. In addition, the source of information can also be personal, which does not require an institution and does not require permission to disseminate information specifically. The development of communication and information technology further facilitates the interaction between individuals and groups. Message traffic and reporting are not fully controlled by the state but are free to flow to the public [1]. As long as 
the source or sender of information is deemed to have credibility in the eyes of the recipient of the information, then the information disseminated tends to be considered having factually reliable values.

Social media is one of the digital communication and information media that is rapidly developing. Social media has the power to disseminate information as an option to influence, motivate, and take actions that are desired by message disseminators [1]. Therefore, social media is considered by some as an appropriate medium for conducting persuasion activities, for example in the political field. One of the supporting statements suggests that one of the social media platforms, namely Twitter, has become a channel for contestation and the struggle for political images. But of course, there is a process of construction and deconstruction [2]. Artinya, media sosial dianggap cukup mampu membentuk dan merubah bentuk persepsi komunikan yang diterpanya This means that social media is considered having the ability to shape and change the form of perceptions of the communicant that are exposed to it.

The term process of construction and deconstruction of the image of a politician in the political world cannot be separated from the element of framing. Therefore, there is a dichotomy in framing a case on Instagram social media namely, (1) trial by press practice. (2) Who to watch out for; (3) Who is wrong; (4) says like be silence vs be angry [3]. The accompaniment of opinion through this framing led to the appearance of an attitude of agreement or disapproval of the recipient of the message. This is what ultimately results in conflicts that occur among social media users. This incident indicates that social media can play an important role in the information-based conflict in the future [4]. In the end, social media increasingly plays a role in controversial conflicts and politics. Politicians, leaders, opposition, and protesters have all used social media as a communication tool [5]. In fact, social media also plays an important role in various fields. For example, in the field of sending and receiving information, the use of social media should be utilized in efforts to resolve conflicts [6]. However, with the higher use of new media, social interactions will tend to be lower [7]. This further opens up opportunities for conflict, both veiled and open conflicts..

Based on this, this paper intends to describe the use of one of the social media in the political field, WhatsApp, with one of its facilities, namely the WhatsApp group. This facility allows the incorporation of a number of members with different political choices. This difference allows conflict. This includes students from the faculties of social sciences and political sciences, which are specifically assumed to have the provision of social and political intelligence, in accordance with the field of science they are practicing.

\section{Method}

Several studies have discussed about the use of WhatsApp application. The results of these studies include WhatsApp group can be used as a media campaign [8], WhatsApp group is used as a communication media in government organizations [9], Utilization of WhatsApp in measuring employee satisfaction in balancing work and life [10], WhatsApp application is used to expedite the learning process [11], the use of WhatsApp in increasing public awareness in the health sector [12], WhatsApp as a coordination media in Campaign activities [13], and propaganda media [14].

Besides being used as a medium that has positive benefits and impacts, WhatsApp is also alleged to have a negative impact which is described in several kinds of research, namely: 
used as a hoax distribution media [15], negative effects of waste of time and possible openness boundaries of personal identity and privacy [16], as well as symptoms of nomophobia [17], among the users.

The research focuses on the phenomenon of the conflict that occurred on WhatsApp Group, which was attended by students from the Faculty of Social and Political Sciences, Halu Oleo University, Kendari, Indonesia. The method chosen is quantitative descriptive, with data collection techniques using questionnaires through a Google form, observation, and interviews. Respondents chose to fill out the questionnaire.

\section{Results and discussion}

Based on the results of data collection and analysis, it is known that there are several symptoms that can provide an overview of the conflicts that occur in some WhatsApp Groups that were followed by respondents. Regarding the contestation of presidential elections in Indonesia, since 2014 there has been polarization with the strength of the camp increasingly balanced. For students who take education in the field of political science, the phenomenon of presidential elections is certainly a concern for them. Various information received made students have their own choice about the presidential criteria they wanted.

Information received through various types of media is knowledge-giving and also confirms or changes the belief in what they will choose. Information received about presidential candidates is important information for students, especially students who are positioned as beginners or voters who will vote for the first time. This information is often obtained from the WhatsApp Group. Based on the results of field data, it is known that respondents chose to join several WhatsApp groups with various motives. There were $94 \%$ of respondents mentioning that they had a WhatsApp Group that contained quite a number of members, which numbered more than 25 people, as described in Figure 1.

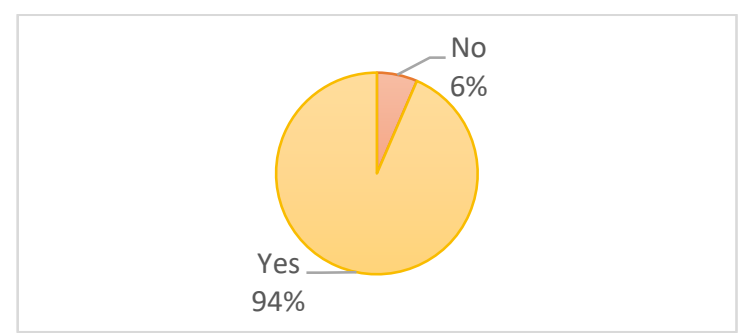

Fig.1. Connectivity in WhatsApp groups with a minimum number of 25 people

There are several WhatsApp Groups (WAG) that were followed by respondents such as, WAG for families, friends during elementary, junior high, high school, class, task groups, courses, organizations followed, to exclusive friendship groups. There are WAGs with more than 25 members, for example, WAG whose members are friends from elementary, junior high, high school, class, and organizing. In some WAGs, they stated that they were actively posting, but in some WAGs, they stated as silent readers and only occasionally commented.

The activity of respondents in interacting in WAG is usually due to the existence of ties with fellow members or interest in the topics discussed in the WAG. This is related to the reason for being in a group on WhatsApp social media, according to one study: a) bonding, b) 
sharing, c) ease of contact, and d) information needs [18]. This shows that WhatsApp can open new opportunities to communicate more closely and intimate [19], especially among members who feel they have a certain bond.

In some WAGs, respondents said they rarely gave comments because they did not feel interested in sending information. This is in line with the opinion that someone's presence in the group on WhatsApp social media is basically just to meet his personal needs, someone wants to get something from the group, not someone wants to give something to the group [18]. In that position, the respondent acts as a silent reader who occasionally reads posts quickly and does not give any comments on the contents of the posts in the WAG that he follows.

Furthermore, based on data collected in the field, it is known that there are a number of students following a number of WAGs. There were respondents who joined and joined in 20 $45 \mathrm{WAG}$, with a number of members above 25 people. However, most of them stated that they joined the WAG only from 3 to 20 WAGs. The visuals are illustrated in Figure 2.

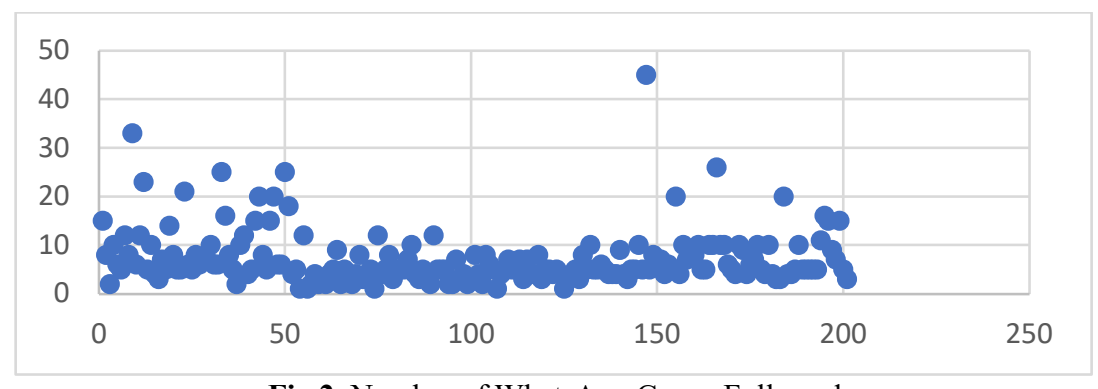

Fig.2. Number of WhatsApp Group Followed

Technological advances have caused changes in people's patterns of consuming news. Now people prefer to read news through private channels on social media, one of which is the WhatsApp Group [20]. Based on these statements, it can be said that WAG is one of the social media applications that are quite attractive to respondents. This can also be caused because the use of WAG is relatively easy, because people use WhatsApp through various devices, including smartphones, laptops, desktops, and tablets [21].

Furthermore, problems can occur through WhatsApp, when they discuss in a group that is homogeneous. The absence of a comparative argument can lead to the emergence of a false belief in something [20]. The homogeneity of WAG members is very possible because usually individuals will choose and feel comfortable joining WAG with specific goals and containing members who share the same vision.

But there are times when the WAG is formed not because of the vision of the same member, but because members have a connected identity, such as WAG which consists of high school alumni. Because of the identity of the high school alumni, individuals become members of certain WAGs, even though they may not feel the same vision as other WAG members in various ways. As individuals who come from communities with a collective culture, respondents tend to be reluctant to leave groups, even though the topics being discussed and comments that discuss a topic are not in tune with his vision. At this point, the respondent chose to be a silent reader, skipping read, or not read the contents of the post at all. This is done to avoid conflict.

One of the hot topics usually discussed in the WAG is the topic of the presidential election. Due to the polarized opinion of the community, one camp tends to reject information and 
persuasion by other camps. So that conflicts can occur at WAG followed by respondents. A total of 103 respondents from 201 respondents stated that they had found a conflict regarding the presidential election that took place at the WAG, as explained in Figure 3.

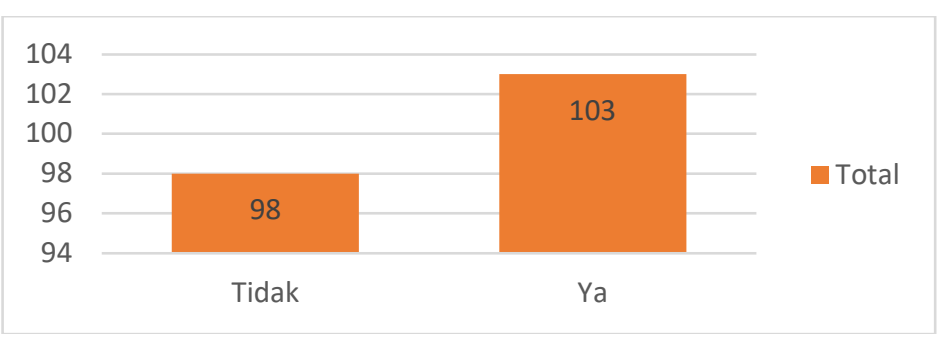

Fig.3. There was a conflict about the presidential election in the group that was followed

In principle, by entering the freedom of communication after political reform in Indonesia, political talks in open forums that criticize government policy are commonplace [22]. Political talk now does not only occur in the elite. The community began to get used to and eloquently fierce discussion about the presidential election, even in the chat of public transportation (angkot) drivers in even coffee shops, which often produce prolonged feuds.

The same thing happened between students who joined in a WAG. Conflict usually occurs because there are members of the group conveying messages that do not depart from the similarity of group members, namely the interests and initial goals of the group formation [23], but because of personal mission. For example in the WAG of high school alumni who aim to maintain friendship and friendship, there is a member who shares posts about something that is ultimately related to one of the presidential contestants. This kind of event eventually led to conflict, because the content of the post was considered unethical because it was irrelevant to the basic purpose of making a group, and was considered provoking debate among members who were certainly not the same standard of values, vision and camp, related to this presidential election.

Therefore, it can be said that the increasing number of conflicts that occur in the use of social media is related to differences in values adopted [24], including differences in taste in choosing a president. In fact, in the field of political education, social media can act as a tool to expand the space for democracy, but it can also cause destabilization of peace [25], including the peace felt by members of a WAG which ultimately raises disharmony.

\section{Conclusion}

Most of the students of the social sciences and political sciences at Halu Oleo University are members of the WAG which are joined by many members, and from some WAGs that they are participating in have conflicts related to the presidential election, which is a hot issue that has occurred in Indonesian society since 2014. what happened in the WAG was stated to have partly led to the act of leaving a group carried out by several members, after the debate had begun.

The debate and conflict that occurred on the WhatsApp group, showed that as a communication media, WhatsApp Group had a role in increasing, while reducing the level of closeness among group members. Even though the initial goal of group formation was based on the desire to establish closer communication between members who were friends and 
partners. The awareness of members on the initial purpose of forming WAG is expected to minimize possible conflicts in the WAG, so that the conditions of relations between members can be harmonious.

\section{References}

[1] E. H. Susanto, "Media Sosial Sebagai Pendukung Jaringan Komunikasi Politik," J. ASPIKOM, vol. 3, no. 3, pp. 379-398, 2017.

[2] Rusmulyadi and H. Hafiar, "Dekonstruksi Citra Politik Jokowi dalam Media Sosial," PRofesi Humas, vol. 3, no. 1, pp. 120-140, 2018.

[3] A. T. Aminuddin, "Instagram: Bingkai Kasus Agama Di Media Sosial," J. Messenger, vol. 9, no. 2, pp. 163-175, 2017.

[4] B. Van Niekerk and M. Maharaj, "Social Media and Information Conflict," Int. J. Commun., vol. 7, pp. 1162-1184, 2013.

[5] T. Zeitzoff, "How Social Media Is Changing Conflict," J. Conflict Resolut., vol. XX, no. X, pp. $1-22,2017$.

[6] F. O. Iroka, "The Social Media and Conflict Resolution,” Int. J. Soc. Sci. Humanit., vol. 11, no. 2, pp. 11-19, 2016.

[7] A. Efendi, P. I. Astuti, and T. Rahayu, "Analisis Pengaruh Penggunaan Media Baru Terhadap Pola Interaksi Sosial Anak Di Kabupaten Sukoharjo," J. Penelit. Hum., vol. 18, no. 1, pp. 12 24, 2017.

[8] H. Hafiar and S. Lukman, "Optimalisasi Kegiatan Promosi Melalui Grup WhatsApp ( WAG ) Dalam Menjaring Calon Peserta Pesantren Kilat,” Promedia, vol. 4, no. 1, pp. 56-75, 2018.

[9] R. Rahmansari, "Penggunaan Aplikasi WhatsApp dalam Komunikasi Organisasi Pegawai Dinas Lingkungan Hidup dan Kebersihan Sidoarjo,” J. Ilm. Manaj. Publik dan Kebijak. Sos., vol. 1, no. 2, pp. 77-90, 2017.

[10] M. K. Omar, A. Zakaria, and Z. I. A. Ismail, "WhatsApp messenger, workload and satisfaction with work-life balance among employees of a Malaysian government office," Int. J. Adv. Appl. Sci., vol. 4, no. 9, pp. 114-118, 2017.

[11] A. Susilo, "Exploring Facebook and WhatsApp As Supporting Social Network Applications For English Learning In Higher Education," Prof. Dev. Educ. Teach. Learn. 21st Century Challenges Lect. Teach., pp. 10-24, 2008.

[12] K. Komariah and P. Subekti, "Penggunaan Media Massa Sebagai Agen Sosialisasi Dinas Kesadaran Masyarakat Akan Pentingnya Imunisasi," PRofesi Humas, vol. 1, no. 1, pp. 12-21, 2016.

[13] F. Y. Permana, "Perempuan dalam kampanye antikorupsi," J. ASPIKOM, vol. 3, no. 3, pp. 399413, 2017.

[14] N. H. Jaafar and S. N. S. Umor, "Social media utilization for islamic da'wah," Res. Hub, vol. 3, no. 10 , pp. $15-23,2017$.

[15] A. Venus, A. Prabalistia, and M. Octavianti, "Analysis of hoax contents on six WhatsApp group," PRroceeding 1st Dharma Duta Fac. Int. Semin. Commun. Tour. Cult. Law Soc. Sci., 2017.

[16] A. Sinha, R. K. Yadav, and R. Kanodia, "Social media : positive vs negative effect on young generation,” Int. J. Sci. Technol. Manag., vol. 5, no. 1, pp. 484-491, 2016.

[17] A. S. Dongre, I. F. I. Inamdar, and P. P. L. Gattani, "Nomophobia: A Study to Evaluate Mobile Phone Dependence and Impact of Cell Phone on Health.," Natl. J. Community Med., vol. 8, no. 11, p. 688, 2017.

[18] Rahmaniar and R. Anisa, "Studi Deskriptif Tentang Loyalitas Peserta Grup WhatsApp," Sosiogobal J. Pemikir. dan Penelit. Sosiol., vol. 2, no. 1, pp. 32-39, 2017.

[19] E. Karapanos, P. Teixeira, and R. Gouveia, "Computers in Human Behavior Need ful fi llment and experiences on social media: A case on Facebook and WhatsApp," Comput. Human 
Behav., vol. 55, pp. 888-897, 2016.

[20] O. M. Bafadhal, "Komunikasi Ritual Penggunaan Aplikasi WhatsApp : Studi Konsumsi Berita Lewat Group WhatsApp,” J. Komun. Indones., vol. V, no. 1, pp. 49-56, 2017.

[21] M. Nouwens, C. Griggio, and W. E. Mackay, "WhatsApp is for family; Messenger is for friends Communication Places in App Ecosystems," Proc. 2017 CHI Con-ference Hum. Factors Comput. Syst. May 2017, Denver, United States, pp. 727-735, 2017.

[22] E. H. Susanto, "Dinamika Komunikasi Politik Dalam Pemilihan Umum,” J. Kaji. Komun., vol. 1, no. 2, pp. 163-172, 2013.

[23] T. Kharisma, "Konflik Sara Pada Pilkada DKI Jakarta Di Grup WhatsApp Dengan Anggota Multikultura," J. Penelit. Komun., vol. 20, no. 2, pp. 107-120, 2017.

[24] G. de Graaf and A. Meijer, "Social Media and Value Conflicts: An Explorative Study of the Dutch Police," Public Adm. Rev., vol. 79, no. 1, pp. 82-92, 2019.

[25] N. A. Kirea, B. Malakwen, and M. Lumala, "Challenges Facing Social Media Platforms In Conflict Prevention In Kenya Since 2007 : A Case Of Ushahidi Platform," Int. Acad. J. Soc. Sci. Educ. |, vol. 2, no. 1, pp. 88-101, 2018. 